\title{
Exclusive abdominal lymphadenopathy as a rare presentation of sarcoidosis
}

\author{
Linfadenopatia abdominal exclusiva como apresentação rara de sarcoidose
}

\section{Matheus de Carvalho Santos ${ }^{1}$, Ana Júlia Araujo de Carvalho' ${ }^{1}$, Helena Telles Furtado dos Santos ${ }^{1}$, Matheus Heringer Gomes ${ }^{1}$, Thiago Arruda Rezende ${ }^{2}$}

Santos MC, Carvalho AJA, Santos HTF, Gomes MH, Rezende TA. Exclusive abdominal lymphadenopathy as a rare presentation of sarcoidosis / Linfadenopatia abdominal exclusiva como apresentação rara de sarcoidose. Rev Med (São Paulo). 2018 NovDec;97(6):585-8.

\begin{abstract}
Introduction: Sarcoidosis is a systemic granulomatous disease. The disease's immunopathogenic mechanism is the activation of a cell mediated immune response. Lung is the most affected organ, but up to $30 \%$ of patients can have extrapulmonary manifestations. Case report: A 21-year-old male presented with a history of nausea, vomiting after meals, epigastric and periumbilical pain for approximately 6 months. Hyporexia and loss of 35 kilograms in 7 months were present, in addition to intermittent low nocturnal fever. His computed tomography (CT) scan (Figure 1) of the abdomen showed the presence of multiple, enlarged mesenteric lymph nodes with homogenous shape, measuring up to $2.0 \mathrm{~cm}$ in diameter, extending from the upper abdomen to the pelvis. Histopathologic findings of this lymph nodes showed a sarcoid appearance (Figure 2). Lymphoma, tuberculosis and other infections were excluded through immunohistochemical analysis. Treatment with prednisone was started initially at a dose of $40 \mathrm{mg}$ and after 5 weeks the patient were asymptomatic. One year and three months after the onset of treatment, corticosteroid dose reduction was attempted 3 times, with all of them leading to disease relapses. Treatment was optimized with $60 \mathrm{mg}$ of prednisone (for 2 weeks) plus $100 \mathrm{mg}$ of azathioprine daily. Discussion: The prevalence of gastrointestinal system involvement with clinical manifestations is 0,1 to $0,9 \%$. However, the incidence of subclinical involvement can be higher. Enlarged lymph nodes is present in approximately $30 \%$ of cases. Treatment is indicated in sarcoidosis for patients with damage organ function or symptomatic disease and the first-line therapy is corticosteroid.
\end{abstract}

Keywords: Sarcoidosis/therapy; Lymphadenopathy/therapy.
RESUMO: Introdução: A sarcoidose é uma doença granulomatosa sistêmica, sendo que o seu mecanismo imunopatogênico se dá através da ativação de uma resposta imune mediada por células. O pulmão é o órgão mais afetado, porém até $30 \%$ dos pacientes podem ter manifestações extrapulmonares. Relato de Caso: Um homem jovem de 21 anos iniciou com um quadro de náuseas, vômitos pós-alimentares e dor epigástrica e periumbilical por aproximadamente 6 meses. Havia também a presença de hiporexia e perda ponderal de $35 \mathrm{~kg}$ em 7 meses, além de febre baixa diária no período da noite. A tomografia computadorizada (TC) da região abdominal mostrou a presença de múltiplos linfonodos mesentéricos aumentados de tamanho, com formato homogêneo, medindo até $2,0 \mathrm{~cm}$ de diâmetro, se estendendo do abdome superior até a pelve. A análise histopatológica desses linfonodos evidenciou uma aparência sarcoide, sendo que linfoma, tuberculose e outras doenças infecciosas foram excluídas através de análise imuno-histoquímica. O tratamento foi iniciado com prednisona inicialmente na dose de $40 \mathrm{mg}$ diariamente e depois de 5 semanas o paciente estava assintomático. Um ano e três meses depois do início do tratamento a redução da dose do corticoide foi tentada por 3 vezes, com todas elas levando à recidivas da doença. $\mathrm{O}$ tratamento foi, então, otimizado com $60 \mathrm{mg}$ de prednisona (por 2 semanas) com $100 \mathrm{mg}$ de azatioprina diariamente. Discussão: A prevalência do envolvimento do sistema gastrointestinal na sarcoidose com manifestações clínicas é de 0,1 a $0,9 \%$. Entretanto, a incidência de envolvimento subclínico pode ser maior do que isso. A linfonodomegalia está presente em aproximadamente $30 \%$ dos casos. O tratamento da sarcoidose está indicado para aqueles pacientes com lesão funcional de órgãos ou doença sintomática, sendo os corticoides a primeira linha de terapia indicada.

Descritores: Sarcoidose/terapia; Linfadenopatia/terapia.

Case Report. Oswaldo Cruz Awards. XXXVII Congresso Médico Universitário, Faculdade de Medicina da USP, SP, Sept. 2018.

1. Student author. Univsersidade Federal de Uberlândia / Federal University of Uberlandia. ORCID: Santos MC - https://orcid.org/0000-0003-00330387; Carvalho AJA - https://orcid.org/0000-0003-3735-1843; Santos HTF - https://orcid.org/0000-0001-5892-911X; Gomes MH - https://orcid. org/0000-0002-9488-7225.

2. Academic advisor. Universidade Federal de Uberlândia (UFU) / Federal University of Uberlandia.

Corresponding author: Matheus de Carvalho Santos. Rua Franscisco Antônio de Oliveira, 1211. Uberlândia, MG, Brazil. E-mail: matheuscs@ufu.br. 


\section{INTRODUCTION}

arcoidosis is a systemic granulomatous disease $\checkmark$ characterized by the presence of noncaseating granulomas in many organs, mainly the lungs. The prevalence of disease varies according to race, age and geographic regions, being more prevalent among young and middle age adults (e.g. 70\% of patients aged $25-45$ years), northern European and African-American individuals ${ }^{1,2,3}$.

The etiology and pathogenesis are still not defined, but studies suggested that environmental and genetic susceptibility contribute to disease development. Mycobacteria and propionibacteria have been identified as possible causative agents. Other environmental factors are related to exposure to emissions from wood-burning stoves, tree pollen, insecticides and moldy environments. Some genes are referred to be associated with sarcoidosis, such as HLA-B8, HLA-DRB1 and DQB1 alleles, butyrophilinlike 2 (BTNL2) ${ }^{1,2,3}$.

The immunopathogenic mechanism is related to the activation of a cell mediated immune response, leading to granuloma formation and distortion of normal microarchitecture. In sarcoidosis, there is activation of type 1 Thelper cells that secrete predominantly interleukin-2 and interferon- $\gamma$, increase in macrophage TNF- $\alpha$ production, and amplification of the local cellular immune response. Also, studies found a reduced number of regulatory T cells and natural killer T cells in the peripheral blood of patients with sarcoidosis ${ }^{1,2,3}$.

Lung is the most affected organ, with statistics indicating that $90 \%$ of patients with sarcoidosis have some kind of thoracic involvement. Symmetrical hilar adenopathy is the most common thoracic manifestation and diffuse interstitial lung disease is the classic type of lung involvement, but patients can present with pneumothorax, pleural thickening, chylothorax and pulmonary hypertension ${ }^{4}$. Up to $30 \%$ of patients can have extrapulmonary manifestations and the most common sites are skin, eyes, reticuloendothelial system, musculoskeletal system, exocrine glands, heart, kidney and central nervous

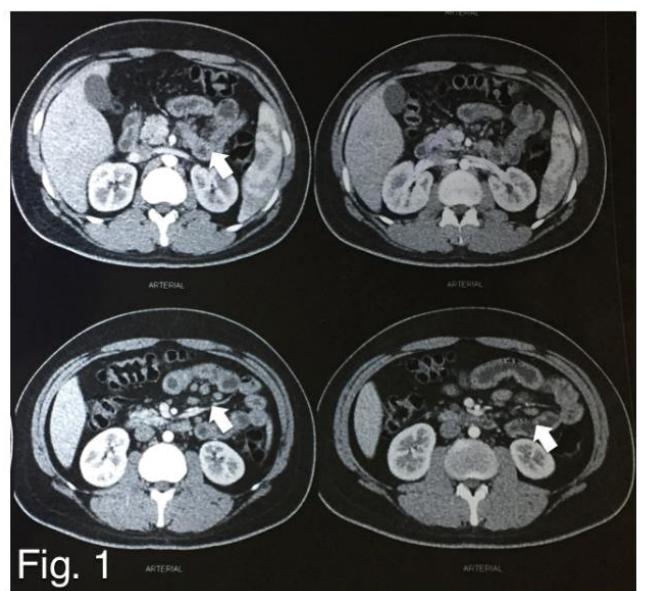

Figure 1: Computed tomography (CT) scan showing multiple enlarged abdominal lymph nodes (white arrows) system. Systemic symptoms such as fatigue, night sweats, and weight loss are common ${ }^{5}$.

Diagnostic of sarcoidosis is made based on three criteria: compatible clinical and radiological presentation, histopathologic detection of noncaseating granulomas and exclusion of other diseases that may present similarly. The decision to treat sarcoidosis is based on the activity and extent of disease, being the use of immunosuppressive agents, mainly corticosteroids, the treatment of choice ${ }^{6}$.

\section{CASE REPORT}

A 21-year-old male showed up with a history of nausea and vomiting after meals, up to four times a day for approximately 6 months. He also had moderate to severe epigastric and periumbilical pain, which improved after eating and worsened with fasting. Hyporexia and loss of 35 kilograms in 7 months were present, in addition to weekly intermittent low nocturnal fever.

Initially, increased CRP (C-Reactive Protein) and ESR (erythrocyte sedimentation rate) were detected (40mg/ $\mathrm{dl}$ CRP and $87 \mathrm{~mm}$ ESR), plus an iron deficiency anemia. The patient underwent proton pump inhibitor use for 6 weeks without any improvement. Endoscopic examination revealed pangastritis and moderate duodenitis.

After these findings, a computed tomography (CT) scan (Figure 1) of the abdomen was requested and showed the presence of multiple, enlarged mesenteric lymph nodes with homogenous shape, measuring up to $2.0 \mathrm{~cm}$ in diameter, extending from the upper abdomen, peripancreatic, paraaortic to the pelvis. Chest CT showed no lymphadenomegaly. It was also requested an enterotomography which showed normal intestinal loops, but confirmed the previously detected lymphadenomegaly. In view of these results, excisional biopsy of a few lymph nodes was performed through video laparoscopy. At the microscope, the lymph nodes resembled a sarcoid appearance (Figure 2), indicating sarcoidosis which was exclusive to the retroperitoneal lymph nodes. In addition, lymphoma, tuberculosis and other infections were excluded through immunohistochemical analysis.

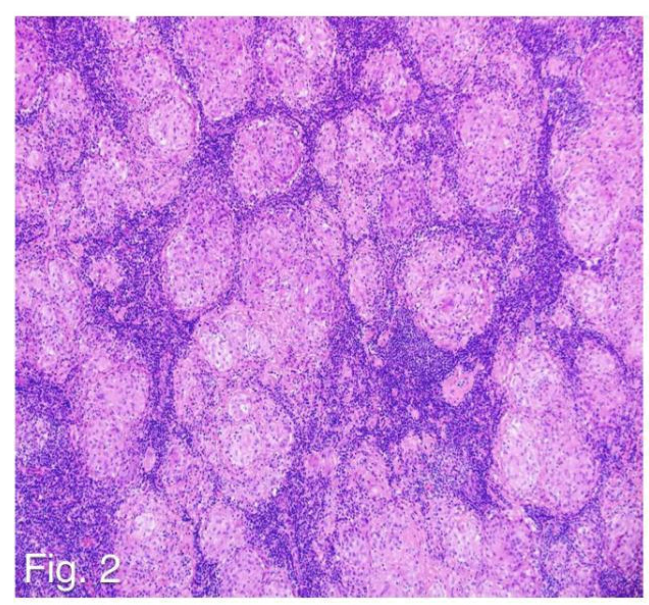

Figure 2: Microscopic view of an excised lymph node showing the characteristic sarcoid appearance 
Treatment with an oral systemic corticosteroid (prednisone) was started initially at a dose of $40 \mathrm{mg}$. After 2 weeks, the patient reported symptomatic improvement and after 5 weeks the patient reported to be asymptomatic. Magnetic resonance imaging and control laboratory tests became normal.

One year and three months after the onset of treatment, corticosteroid dose reduction was attempted 3 times, with all of them leading to disease relapses consisting of recurrence of symptoms. Routine laboratory exams exhibited signs of inflammation (though milder than before treatment) and a new CT was performed showing abdominal lymphadenomegaly with the same previous characteristics.

Treatment was optimized with $60 \mathrm{mg}$ of prednisone (for 2 weeks) plus 100mg of azathioprine daily. After this initial period, the patient reported symptomatic improvement, with the latest information given is that the patient is almost asymptomatic as of now.

\section{DISCUSSION}

Sarcoidosis is a systemic disease of unknown etiology, characterized by the formation of noncaseating granulomas. Although pulmonary involvement is the most common, $30 \%$ of patients present with extrapulmonary sarcoidosis, being the abdomen the most common extrathoracic site $(50-70 \%)^{7}$.

The prevalence of gastrointestinal system involvement in sarcoidosis with clinical manifestations is 0,1 to $0,9 \%{ }^{6}$. However, the incidence of subclinical involvement can be higher, since gastrointestinal involvement is normally underdiagnosed because patients with sarcoidosis generally do no present with abdominal symptomatology ${ }^{8}$.

The symptoms of gastrointestinal sarcoidosis may occur in patients who are already diagnosed with the disease in other organs or they can represent the initial manifestation. The most common symptoms of gastrointestinal sarcoidosis are nausea, vomiting, weight loss, diarrhea, and epigastric pain. In addition, gastrointestinal forms can include: periumbilical pain, fever, dysphagia, hoarseness and odynophagia ${ }^{6}$.

Enlarged lymph nodes are present in approximately $30 \%$ of cases, being paraaortic, portal, peripancreatic and epigastric the most affected ${ }^{8}$. The lymph nodes are typically smaller than $2 \mathrm{~cm}$ in diameter and more discrete rather than confluent, the involvement of the retrocrural area is less common. The characteristics of this lymph nodes on CT are: soft tissue attenuation, mildly enhanced with gadolinium in T1 images and homogeneously hyperintense appearance or central hypointensity surrounded by peripheral high signal intensity on $\mathrm{T} 2$ images $^{7}$.

These features of gastrointestinal sarcoidosis make the disease a differential diagnosis with neoplastic or infectious disease, such as lymphoma, granulomatous or mycobacterial infections, fungal and parasitic infections, Whipple's disease and Crohn's disease ${ }^{7}$.

Abdominal sarcoidosis can occur in the absence of pulmonary disease, as shown in this case ${ }^{7}$. This patient presented with epigastric and periumbilical pain, nausea, vomiting and weight loss. His CT showed enlargement of mesenteric, paraaortic, peripancreatic and pelvic lymph nodes and the histopathologic findings were consistent with sarcoidosis. Also, other diseases that can present similarly were excluded from the diagnosis. Therefore, all the three criteria to meet the diagnosis of sarcoidosis were filled: the patient had a compatible clinical presentation, radiological features consistent with gastrointestinal sarcoidosis and the findings of noncaseating granulomas upon histopathologic exam.

Treatment is indicated in sarcoidosis for patients whose organ function is threatened or in symptomatic disease, as the patient in this case presented ${ }^{9}$. Treatment is not indicated in all cases because the disease can be self-limiting and have a spontaneous remission within 2-3 years in a majority of patients ${ }^{10}$. The decisions about the treatment of sarcoidosis still are a challenge: there is still not a protocol validated to institute, maintain and tapper down the therapy, besides the vast majority of studies is destined only or mainly towards pulmonary sarcoidosis. First-line therapy consists in the use of glucocorticoids and glucocorticosteroid-like agents ${ }^{9}$.

An international consensus statement recommends initiating treatment with oral prednisone at a dose of 20 to $40 \mathrm{mg}$ per day for four to six weeks. If the patient presents a response to treatment, dosage should be tapered slowly to approximately 5 to $10 \mathrm{mg}$ per day and this should be continued for 12 months ${ }^{9}$. Recent studies show that alternative corticosteroid therapy may be necessary, especially if the patient is refractory or if there is a need to spare the use of corticosteroid because of its side effects, such as excessive weight gain, osteoporosis, diabetes mellitus, hypertension, gastritis, myopathy and opportunistic infections ${ }^{10,11,13}$.

As the patient in this case presented with relapses after trying to taper prednisone, second-line agents were included in his therapy: cytotoxic agents, such as methotrexate, azathioprine, leflunomide and antimalarials drugs. ${ }^{13}$ Methotrexate is considered to be the first-choice option in sarcoidosis, because there is a large number of trials supporting its use for both pulmonary and extrapulmonary disease, although, a retrospective trial compared the effects of azathioprine and methotrexate in pulmonary sarcoidosis and it concluded that medications had similar effects and both presented substantial steroidsparing capacities and comparable side-effect profiles, except for a higher rate of infections with azathioprine ${ }^{10,11,12}$. 
Studies about pulmonary sarcoidosis show that the disease resolves spontaneously within 2 years and after 5 years the remission is much less likely. Relapses after treatment are common and most often occur two to six months after corticosteroid withdrawal, but rarely after three years without symptoms?.

This case was searched in the main databases of the global medical literature and practically no original material was found. The incidence of sarcoidosis in the described

\section{REFERENCES}

1. Valeyre D, Prasse A, Nunes H, Uzunhan Y, Brillet PY, MüllerQuernheim J. Sarcoidosis. Lancet. 2014;383(9923):1155-67. doi: 10.1016/S0140-6736(13)60680-7.

2. Iannuzzi MC, Fontana JR. Sarcoidosis: clinical presentation, immunopathogenesis, and therapeutics. JAMA. 2011;305(4):391-9. doi: 10.1001/jama.2011.10.

3. Lannuzzi MC, Rybicki BA, Teirstein AS: Sarcoidosis. N Engl J Med. 2007;357(21):2153-65. doi: 10.1056/NEJMra071714.

4. Judson MA. The clinical features of sarcoidosis: a comprehensive review. Clin Rev Allergy Immunol. 2015;49(1):63-78. doi: 10.1007/s12016-014-8450-y.

5. King TE. Extrapulmonary manifestations of sarcoidosis. UpToDate. Available from: https://www.uptodate.com/ contents/extrapulmonary-manifestations-of-sarcoidosis/print.

6. Berman JS, Govender P. Gastrointestinal and hepatic sarcoidosis. UpToDate. Available from: https://www.uptodate. com/contents/gastrointestinal-and-hepatic-sarcoidosis.

7. Gezer NS, Başara I, Altay C, Harman M, Rocher L, Karabulut N, Seçil M. Abdominal sarcoidosis: cross-sectional imaging findings. Diagn Interv Radiol. 2015;21(2):111-7. doi: 10.5152/ dir.2014.14210. form (intra-abdominal lymph node involvement not associated with GI mucosal disease and without pulmonary involvement) is extremely uncommon, a factor that caused the diagnosis process to take about 6 months to be obtained. In addition, the case shows the importance of the differential diagnosis of abdominal lymphadenopathy, since this finding can translate into the most diverse pathologies that can have completely different therapeutic management.

8. Deutch SJ, Sandler MA, Tankanow LB. Abdominal lymphadenopathy in sarcoidosis. J Ultrasound Med. 1987;6:237-42. https://doi.org/10.7863/jum.1987.6.5.237.

9. Soto-Gomez N, Peters JI, Nambiar AM. Diagnosis and management of sarcoidosis. Am Fam Physician. 2016 May 15;93(10):840-8. Available from: https://www.aafp.org/ afp/2016/0515/p840.html.

10. Vorselaars Adriane D M, Cremers Johanna P, Grutters Jan C, Drent Marjolein. Cytotoxic agents in sarcoidosis: which one should we choose? Curr Opin Pulm Med. 2014;20(5):479-87. doi: 10.1097/MCP.0000000000000078.

11. Baughman RP, Lower EE. Treatment of sarcoidosis. Clin Rev Allergy Immunol. 2015;49(1):79-92. doi: 10.1007/ s12016-015-8492-9.

12. Korsten P, Mirsaeidi M, Sweiss NJ. Nonsteroidal therapy of sarcoidosis. Curr Opin Pulm Med. 2013;19(5):516-23. doi: 10.1097/MCP.0b013e3283642ad0.

13. Shinn J, Paauw DS. The management of sarcoidosis: a primary care approach. Med Clin North Am. 2015;99(5):1123-48. doi: 10.1016/j.mena.2015.05.008. 